\title{
Recent patent applications in nitric oxide research
}

\begin{tabular}{ll} 
Patent \# & Subject \\
\hline WO 9839291 & $\begin{array}{l}\text { New 3- or 4-thiol cyclopentane derivatives: topoisomerase II and IGE } \\
\text { inhibitors and apoptosis inducers used for treating, e.g., bacterial } \\
\text { infections, allergies, and nitric oxide-mediated diseases, including } \\
\text { hypertension, cerebral ischemia, and hyperdipichemia. }\end{array}$
\end{tabular}

WO 9838320 New isolated bromelain component protein; used for treating cancers or diseases responding to increased nitric oxide production or as a vaccine adjuvant or antimicrobial agent.

WO 9837079 New nitric oxide synthase inhibiting N-heterocyclic compounds; used to treat, e.g., inflammatory and autoimmune diseases, multiple sclerosis, stroke, Parkinson's disease, and Alzheimer's disease.

WO 9835667 Treatment or prophylaxis of type-2 diabetes by administration of amino-guanidine or other nitric oxide synthase inhibitors.

WO 9834955 Hemoglobin(s) modified with S-nitroso groups, and related compounds; used in treatment of ischemic injury, hypertension, angina, reperfusion injury, or inflammation.

WO 9834626 Compounds for reducing ischemia/reperfusion injury, using a combination of an inhibitor of iNOS induction, a nitric oxide donor, and an endopeptidase inhibitor.

WO 9833519 Nucleic acid encoding arginine deiminase of Mycoplasma arthritidis; useful for treating tumors, cancers, and nitric oxide-related conditions.

US 5789024 Self-terminating low-pressure chemical vapor deposition process to form a composite membrane filter; allows nitrous oxide and silane reactant gases to deposit in the pores of a mesoporous substrate to separate combinations of gases and liquids in food processing, biotechnology, pharmaceuticals, and petrochemicals.

WO 9830537 New (imino-ethyl-amino)ethyl-homocysteine inhibits nitric oxide synthase; used to treat arthritis, asthma, ileus and migraine.

WO 9830220 Prevention of opioid tolerance, particularly to morphine, in the clinical management of moderate to severe pain, by administering an inducible nitric oxide inhibitor.

WO 9827108 New amide compounds for treatment of nitric oxide-mediated diseases such as cardiovascular ischemia, diabetes, cerebral infarction, and asthma.

FR 2757864 Antibodies specific for nitrosylated protein(s); used to treat, prevent, or diagnose disorders involving nitric oxide, e.g., infection, septic shock, cancer, autoimmune disease, etc.

WO 9828257 New aromatic amine derivatives: nitric oxide synthase inhibitors for treating cerebrovascular diseases such as cerebral hemorrhage and, e.g., Alzheimer's disease and diabetes.

Assignee
Takara Shuzo Co.
Ltd. (Shiga, Japan)
Cortecs UK Ltd.
(Flintshire, UK)
Berlex Lab. Inc.
(Wayne, NJ);
Pharmacopeia Inc.
(Princeton, NJ)

(Princeton, NJ)

SmithKline

Beecham (London)

Duke Univ. Med.

Center

(Durham, NC)

Univ. S. Carolina

(Columbia, SC)

Enzon Inc.

(Piscataway, NJ)

New Jersey Inst.

Technology

(Newark, NJ)

Glaxo Group Ltd. (London)

G.D. Searle \& Co. (Skokie, IL)

Fujisawa Pharm Co.Ltd. (Osaka, Japan); Yatabe T

Cent. Natl. Rech. Sci. (Paris)

Chugai Seiyaku

KK (Tokyo)

Ariad Gene

Therapeutics Inc. (Cambridge, MA)

Merck \& Co. Inc.

(Whitehouse Sta., NJ) RA, Nathan CF, Xie Q

\section{Author}

Chono H, Enoki T, Date Status

Hagiya M, Ikai K,

Kato I, Koyama N,

Nishiyama E, Ohnogi $\mathrm{H}$,

Sagawa $\mathrm{H}$, Tominagawa

$\mathrm{T}, \mathrm{WuH}$

Engwerda C, Mynott

$9 / 3 / 98$

A1

TL, Peek K

$9 / 11 / 98$

A1

Arnaiz DO, Baldwin JJ, 8/27/98

A1

Davey DD, Devlin JJ,

Dolle RE, Erickson SD,

McMillan K, Morrissey

$\mathrm{MM}$, Ohlmeyer $\mathrm{HHJ}$,

Pan G, Paradkar VM,

Parkinson J, Phillips GB,

Ye B, Zhao Z

Piercy V, Turner NC

$8 / 20 / 98$

A1

Gow AJ, Stamler JS

$8 / 13 / 98$

A1

Singh I

$8 / 13 / 98$

A1

Filpula DR, Wang M

$8 / 6 / 98$

A1

Levy RA, Ramos ES $\quad$ 8/4/98 A

WO 9826066 New method for treating or preventing asthma; comprises use of DNA encoding IFN-gamma, IL-10, IL-12 or nitric oxide synthase and DNA for control of expression using a ligand.

US 5766909 DNA molecules encoding inducible nitric oxide synthase proteins; useful for producing recombinant proteins.

Beams RM, Drysdale
MJ, Franzman KW, Frend

AJ, Hodson HF, Knowles

RG, Rees DD, Sawyer DA

Salvemini D

$7 / 16 / 98$

Hamashima H, Inoue T, 6/25/98 Itoh Y, Ohne K, Oku T,

Shima I, Yatabe T,

Yoshihara K

Chagnaud JL, Geffard 7/9/98

$M$, Veyret B, Vincendeau

$\mathrm{P}$, Chagnaud $\mathrm{J}$

Esaki T, Makino T,

Nagafuji T, Nishimura $Y$

$7 / 2 / 98 \quad A 1$

Cerasoli F

$6 / 18 / 98$

Source: Derwent Information, Alexandria, VA. *The patents in the table are pending. The status of each application is slightly different from country to country. For further details, contact Derwent Information, 1725 Duke St., Suite 250, Alexandria, VA 22314. Tel: 1 (800) DERWENT (info@derwent.com). 